\title{
Effect of refrigerated storage on probiotic viability and the production and stability of antimutagenic and antioxidant peptides in yogurt supplemented with pineapple peel
}

\author{
B. N. P. Sah, ${ }^{*}$ T. Vasiljevic, ${ }^{*}$ S. McKechnie, $\dagger$ and O. N. Donkor ${ }^{* 1}$ \\ ${ }^{*}$ College of Health and Biomedicine, and \\ †College of Engineering and Science, Advanced Food Systems Research Unit, Victoria University, Werribee Campus, PO Box 14428, \\ Melbourne, Victoria 8001, Australia
}

\begin{abstract}
Fruit by-products are good resources of carbohydrates, proteins, vitamins, and minerals, which may function as growth nutrients for probiotic bacteria. This research aimed at evaluating effects of pineapple peel powder addition on the viability and activity of Lactobacillus acidophilus (ATCC 4356), Lactobacillus casei (ATCC 393), and Lactobacillus paracasei ssp. paracasei (ATCC BAA52) in yogurts throughout storage at $4^{\circ} \mathrm{C}$ for $28 \mathrm{~d}$. Plain and probiotic yogurts supplemented with or without pineapple peel powder or inulin were prepared. The probiotic counts in supplemented yogurts at $28 \mathrm{~d}$ of storage ranged from 7.68 and $8.03 \mathrm{log} \mathrm{cfu} / \mathrm{g}$, one log cycle higher compared with nonsupplemented control yogurt. Degree of proteolysis in synbiotic yogurts was significantly higher than plain yogurts and increased substantially during storage. Crude watersoluble peptide extract of the probiotic yogurt with peel possessed stronger antimutagenic and antioxidant activities [evaluated measuring reducing power and scavenging capacity of 1,1-diphenyl-2-picrylhydrazyl; 2,2'-azino-bis(3-ethyl benzothiazoline-6-sulfonic acid), and hydroxyl radicals] than control and maintained during storage. Pineapple peel, a by-product of juice production, could be proposed as a prebiotic ingredient in the manufacture of yogurts with enhanced nutrition, and functionality.
\end{abstract}

Key words: pineapple, probiotic, peptide, antioxidative activity, and antimutagenic activity

\section{INTRODUCTION}

Demand for development of healthy foods is increasing rapidly due to growing interest of consumers to maintain their health and well-being. Day et al. (2009)

Received February 10, 2015.

Accepted May 18, 2015.

${ }^{1}$ Corresponding author: Osaana.Donkor@vu.edu.au defined functional foods as "foods or ingredients of foods that provide additional physiological benefit beyond their basic nutrition." Milk is considered a source of functional ingredients, such as bioactive peptides, which are encrypted in the primary structure of milk proteins and could modulate physiology of consumers only after their proteolytic release (Bhat and Bhat, 2011). Several possible ways exist to obtain these bioactive peptides to functionalize foods. One way could be through direct release of peptides from proteins by action of proteolytic systems of bacteria commonly used in manufacturing of fermented food products (Choi et al., 2012). Therefore, yogurt appears to be a suitable matrix for production of such functional ingredients.

Yogurt is an excellent vehicle to deliver probiotics to consumers; however, to be beneficial for health, the product should contain the suggested minimum number of $10^{6} \mathrm{cfu} / \mathrm{g}$ at the time of consumption (Shiby and Mishra, 2013; Mani-López et al., 2014). The viability of probiotic organisms is thus considered a key parameter for developing probiotic food products. The major factors for achieving and maintaining this minimal level in yogurt include nutrients, $\mathrm{pH}$, water activity, oxygen tension of the product, storage conditions (e.g., temperature, humidity, and light), the interactions with the starter cultures, as well as strain types (Vasiljevic and Shah, 2008). To minimize their adverse effects, different approaches have been suggested, including microencapsulation of probiotics (Corona-Hernandez et al., 2013), addition of enzymes (Cruz et al., 2013), and prebiotics (Al-Sheraji et al., 2013).

A prebiotic is "a selectively fermented ingredient that allows specific changes, both in the composition or activity in the gastrointestinal microflora that confers benefits upon host well-being and health" (Gibson et al., 2004). Common prebiotics are inulin, fructooligosaccharides, galactooligosaccharides, and other oligosaccharides, such as resistant starch and lactulose (Thammarutwasik et al., 2009). Inulin represents a group of plant polysaccharides having linear fructans 
with $\beta$ - $(2 \leftarrow 1)$ fructosyl-fructose glycosidic linkages and usually prepared by aqueous extraction of chicory roots. However, human digestive enzymes are specific for the hydrolysis of $\alpha$-glycosidic bonds. Consequently, they are indigestible and only fermented by colonic microflora (Roberfroid, 2007). A high-performance type of inulin is a long-chain inulin with degree of polymerization of 10 to 60 , average being 25 . In addition to inulin, pineapple peel powder appeared a good source of dietary fiber and has been reported to show prebiotic potential (Diaz-Vela et al., 2013).

Several investigations (Donkor et al., 2007a; Al-Sheraji et al., 2012) have focused on probiotic viability in yogurt containing prebiotic supplements and during refrigerated storage. Whereas prebiotic supplementations may result into several functional benefits for probiotic organisms and ultimately consumers, this approach may influence the bioactivity of yogurt, as bacterial proteolytic enzymes may further hydrolyze milk proteins as well as bioactive peptides during storage (Donkor et al., 2007b). Notably, milk proteins emerge as a prolific source of peptides with anticarcinogenic potentials (Sah et al., 2015). However, studies are lacking regarding the effects of prebiotic addition on antimutagenic and antioxidant activities of the liberated peptides in yogurt during storage. Thus, our study aimed to assess the effect of pineapple peel powder (PPP) addition on viability and performance of Lactobacillus acidophilus (ATCC 4356), Lactobacillus casei (ATCC 393), and Lactobacillus paracasei ssp. paracasei (ATCC BAA52) in regard to the liberation of bioactive peptides with antioxidant and antimutagenic potentials in yogurts during $28 \mathrm{~d}$ of refrigerated storage.

\section{MATERIALS AND METHODS}

\section{Substrates and Chemicals}

Trichloroacetic acid, o-phthaldialdehyde (OPA), trifluoroacetic acid, 1,1-diphenyl-2-picrylhydrazyl (DPPH), 2,2'-azino-bis (3-ethyl benzothiazoline6-sulfonic acid) (ABTS), salicylic acid, vancomycin, clindamycin, sodium azide, and serine were purchased from Sigma Chemical Company (St. Louis, MO), whereas acetonitrile was from Merck (Darmstadt, Germany). Hydrogen peroxide, ferrous sulfate, and potassium ferricyanide were obtained from Ajax Finechem (Seven Hills, NSW, Australia). Bacteriological agar, M17 medium, de Man Rogosa and Sharpe (MRS) medium, and peptone were supplied by Oxoid Australia (West Heidelberg, Victoria, Australia), whereas Davis minimal agar was purchased from Becton Dickinson Pty Ltd. (Sydney, NSW, Australia). Skim milk powder was procured from a local store (Woolworths Limited,
Melbourne, Australia). Aqueous solutions were prepared in Milli-Q water $(18.2 \mathrm{M} \Omega \cdot \mathrm{cm})$ obtained from a Millipore water-purification system (Millipore, North Ryde, Australia). Whole pineapples were purchased from a local supermarket (Woolworths Limited).

\section{Propagation of Cultures}

Pure cultures of Streptococcus thermophilus ASCC 1275 and Lactobacillus delbrueckii ssp. bulgaricus Lb1466 were obtained from the Victoria University Culture Collection (Werribee, Australia). Lactobacillus acidophilus ATCC 4356, L. casei ATCC 393, and $L$. paracasei spp. paracasei ATCC BAA52 were procured from Cell Biosciences Pty Ltd. (Heidelberg, Victoria, Australia). All organisms were stored at $-80^{\circ} \mathrm{C}$ in MRS broth containing $40 \%$ (vol/vol) glycerol. The resuscitated strains after 3 successive transfers were employed to prepare starters as described by Sah et al. (2014).

\section{Preparation of PPP}

Pineapple peel powder was prepared from the peel of pineapples [Ananas comosus (L.) Merrill], as described by do Espírito Santo et al. (2012) with some modifications. Briefly, crushed peel $(\sim 2 \times 2 \mathrm{~cm}$ sizes $)$ was washed by dipping in hot water $\left(90^{\circ} \mathrm{C}\right)$ for $30 \mathrm{~min}$ to inactivate potential pathogens and proteolytic enzymes (Jutamongkon and Charoenrein, 2010). The peel was then freeze-dried using an Alpha 1-4 LSC Christ freeze dryer (Martin Christ Gefriertrocknungsanlagen GmbH, Osterode, Germany). The dried peel was milled to fine powder, standardized particle size less than $180 \mu \mathrm{m}$ using wire mesh sieves (Endecotts Ltd., London, UK; Mesh Series BS410/1986) and sterilized with UV irradiation for 30 min (Coman et al., 2013).

\section{Preparation of Yogurts Supplemented with Prebiotics}

Set-type plain and probiotic yogurts with inulin or PPP supplementation or without supplementation (control) were prepared as described by Sah et al. (2014) with some modifications. Briefly, 3 batches of milk base were prepared by reconstituting skim milk powder in Milli-Q water at $140 \mathrm{~g} / \mathrm{L} ; 2$ batches were separately supplemented with $1.0 \%$ (wt/vol) of commercial inulin Orafti HP (Beneo-Orafti Ltd., Tienen, Belgium) and PPP. All milk bases were heated for 30 min at $85^{\circ} \mathrm{C}$, cooled to $45^{\circ} \mathrm{C}$, and then inoculated with $1 \%$ (vol/vol) of each S. thermophilus and L. bulgaricus monocultures aseptically. The mixes were divided into 2 equal portions; one portion was further inoculated with $1 \%(\mathrm{vol} / \mathrm{vol})$ of each probiotic monocultures. The final 
mixes were poured into polystyrene cups and incubated at $42^{\circ} \mathrm{C}$ until pH of $4.5 \pm 0.05$ was achieved. Thereafter, the yogurts were immediately cooled to $4^{\circ} \mathrm{C}$ and stored for $28 \mathrm{~d}$ at the same temperature.

\section{Enumeration of Starter and Probiotic Cultures}

Cell populations of starter (S. thermophilus and $L$. bulgaricus) and probiotic (L. acidophilus, L. casei, and L. paracasei) cultures in freshly inoculated yogurt mixes $(0 \mathrm{~h})$ and in yogurts during storage were counted by spread plate technique and expressed as the log of colony-forming units per gram. The selective agar plates and incubation conditions for the cultures were as follows: M17 medium supplemented with lactose and aerobic incubation of $24 \mathrm{~h}$ at $45^{\circ} \mathrm{C}$ for S. thermophilus; acidified MRS agar (pH 5.2) and anaerobic incubation of $72 \mathrm{~h}$ at $45^{\circ} \mathrm{C}$ for L. bulgaricus. Lactobacillus acidophilus and both $L$. casei and L. paracasei together were respectively enumerated using MRS-clindamycin agar (pH 6.2; $0.5 \mathrm{mg} / \mathrm{L}$ clindamycin), MRS-vancomycin agar ( $\mathrm{pH} 6.2 ; 1 \mathrm{mg} / \mathrm{L}$ vancomycin), and anaerobic incubation of $72 \mathrm{~h}$ at $37^{\circ} \mathrm{C}$ (Sah et al., 2014).

\section{Determination of Titratable Acidity}

Titratable acidity (TA), as percent lactic acid, of yogurt samples was determined according to AOAC official method 947.05 (Horwitz and Latimer, 2006) using equation [1]:

$$
\% \mathrm{TA}(\mathrm{wt} / \mathrm{wt}), \text { as lactic acid }=\frac{V \times N \times 90.08}{W \times 10},
$$

where $V=$ volume of $\mathrm{NaOH}$ consumed, $\mathrm{mL} ; N=$ normality of the $\mathrm{NaOH}$; and $W=$ mass of sample, $g$.

\section{Determination of Proteolysis}

Degree of protein hydrolysis was measured using the OPA method as described by Sah et al. (2014) with some modifications. Briefly, $1 \mathrm{~mL}$ of Milli-Q water was added to a 5 -g yogurt sample and the final volume adjusted to $10 \mathrm{~mL}$ with trichloroacetic acid solution $(0.75 \mathrm{M})$. The supernatant collected after centrifugation of the sample at 2,684 $\times g$ for 30 min at $4^{\circ} \mathrm{C}$ was filtered using a $0.45-\mu \mathrm{m}$ Phenex syringe filter (Phenomenex Inc., Lane Cove, Australia). An aliquot of clarified sample (400 $\mu \mathrm{L}$ ) was mixed with $3 \mathrm{~mL}$ of freshly prepared OPA reagent and left to stand for $2 \mathrm{~min}$. Absorbance of the sample $\left(\mathrm{A}_{\text {sample }}\right)$ was then measured using a Biochrom Libra S12 UV/Vis spectrophotometer (Biochrom Ltd., Cambridge, UK) at $340 \mathrm{~nm}$. In place of sample, Milli-Q water was used for the blank $\left(\mathrm{A}_{\text {blank }}\right)$ and serine solution $(0.9516 \mathrm{mEqv} / \mathrm{L})$ for the standard $\left(\mathrm{A}_{\text {standard }}\right)$. Degree of hydrolysis (DH) was estimated using equation [2],

$$
\mathrm{DH}(\%)=\frac{\mathrm{h}}{\mathrm{h}_{\mathrm{tot}}} \times 100,
$$

where $\mathrm{h}_{\text {tot }}$ was total number of peptide bonds per protein equivalent $(8.2 \mathrm{mEq} / \mathrm{g}$ for casein), and $\mathrm{h}$ was number of hydrolyzed bonds, determined by using equation [3]:

$$
\mathrm{h}=\frac{\left(\text { Serine } \mathrm{NH}_{2}-\beta\right)}{\alpha} .
$$

For casein, $\alpha=1.039, \beta=0.383 \mathrm{mEq} / \mathrm{g}$ of protein, and Serine $\mathrm{NH}_{2}(\mathrm{mEq} / \mathrm{g}$ of protein) was determined using equation [4],

Serine $\mathrm{NH}_{2}=\left[\frac{\left(\mathrm{A}_{\text {sample }}-\mathrm{A}_{\text {blank }}\right)}{\left(\mathrm{A}_{\text {standard }}-\mathrm{A}_{\text {blank }}\right)}\right] \times S \times V \times \frac{100}{X} \times P$,

where $S=$ strength of serine standard, $\mathrm{mEq} / \mathrm{L} ; V=$ final volume make-up of the sample, $\mathrm{L} ; X=$ weight of yogurt sample, $\mathrm{g}$; and $P=$ protein content of yogurt sample, \% (wt/wt).

\section{Preparation and Profiling of Water-Soluble Peptide Extracts}

The water-soluble peptide extracts (WSPE) from yogurts and heat-treated reconstituted skim milk $(\mathrm{pH}-$ adjusted to $4.5 \pm 0.05$ ) were prepared according to Sah et al. (2014) with a few modifications. Briefly, samples were centrifuged at 22,680 $\times g$ using JLA-16.250 rotor in Avanti J-26S XPI High-Performance Centrifuge (Beckman Coulter Inc., Brea, CA) for $30 \mathrm{~min}$ at $4^{\circ} \mathrm{C}$. The supernatant was filtered using a sintered glass crucible to remove coagulated proteins, debris, and cells. The filtrate was freeze-dried using an Alpha 1-4 LSC Christ freeze dryer (Martin Christ Gefriertrocknungsanlagen $\mathrm{GmbH}$ ) at $0.1 \mathrm{mbar}$ for 24 to $36 \mathrm{~h}$ (main drying) and 0.08 mbar for $12 \mathrm{~h}$ (final drying) and stored at $-80^{\circ} \mathrm{C}$ until further analysis. The protein content $(\mathrm{mg} / \mathrm{mL})$ of the WSPE was estimated according to Bradford (1976) using BSA (0.1-1.4 mg/mL) as standards.

The WSPE were also profiled using a reversed-phase HPLC system as described by Sah et al. (2014). Briefly, the samples were loaded using a $20-\mu \mathrm{L}$ injection loop to a Varian HPLC system (Varian Inc., Palo Alto, CA) equipped with a C-18 monomeric column $(5 \mu \mathrm{m}, 300$ $\AA$, $250 \times 4.6 \mathrm{~mm}$; Grace Vydac, Hesperia, CA) and detected eluted peptides at $215 \mathrm{~nm}$. 


\section{Determination of Antimutagenic Activity by the Ames Test}

The antimutagenicity of crude WSPE was assessed in a bacterial reverse mutation assay through the preincubation protocol of Ames test as described by Sah et al. (2014) and conducted using Salmonella enterica ssp. enterica Typhimurium (ATCC 29629; genotype: his, rfa, uvrB-bio) with aqueous sodium azide $(1 \mu \mathrm{g} /$ plate) as a direct mutagen. Briefly, $0.1 \mathrm{~mL}$ of WSPE solution (50 $\pm 1 \mu \mathrm{g}$ of peptide) and $0.1 \mathrm{~mL}$ of sodium azide solution $(1 \mu \mathrm{g})$ were mixed with $0.5 \mathrm{~mL}$ of sodium phosphate buffer $(0.1 \mathrm{M}$; $\mathrm{pH} 7.4)$ in a culture tube. An aliquot $(0.1 \mathrm{~mL})$ of 14 - to 16-h-old culture was inoculated and preincubated for $20 \mathrm{~min}$ at $37^{\circ} \mathrm{C}$. The mix was poured over a Davis minimal agar plate after mixing with $2 \mathrm{~mL}$ of molten top agar at $45^{\circ} \mathrm{C}$. Revertant colonies were enumerated after incubating aerobically at $37^{\circ} \mathrm{C}$ for $48 \mathrm{~h}$. The antimutagenic activity was determined using equation [5]:

$$
\% \text { Inhibition }=\frac{M-S_{1}}{M-S_{0}} \times 100
$$

where $S_{1}=$ revertant colonies per plate induced by mutagen in the presence of peptide extract; $M=$ revertant colonies per plate induced by mutagen alone; and $S_{0}=$ spontaneous revertant colonies per plate.

\section{Determination of Antioxidant Activity}

Assay of Reducing Power. Reducing power of the crude WSPE was evaluated by assessing reduction of $\mathrm{Fe}^{3+}\left(\mathrm{CN}^{-}\right)^{6}$ to $\mathrm{Fe}^{2+}\left(\mathrm{CN}^{-}\right)^{6}$, as described by Jiang et al. (2014) with some modifications. Briefly, $50 \mu \mathrm{L}$ of aqueous WSPE (at $0.5 \mathrm{mg}$ of protein $/ \mathrm{mL}$ ) was mixed with $0.5 \mathrm{~mL}$ of phosphate buffer $(0.2 \mathrm{M}, \mathrm{pH} 6.6)$ and $0.5 \mathrm{~mL}$ of aqueous potassium ferricyanide solution (1\%, wt/ vol). After incubation at $50^{\circ} \mathrm{C}$ for $20 \mathrm{~min}, 0.5 \mathrm{~mL}$ of aqueous trichloroacetic acid solution $(10 \%, \mathrm{wt} / \mathrm{vol})$ was added to terminate the reaction. The reaction mixture was centrifuged at $16,000 \times g$ for $10 \mathrm{~min}$ at room temperature. Finally, $0.5 \mathrm{~mL}$ of the supernatant solution was mixed with $0.5 \mathrm{~mL}$ of Milli-Q water, then $0.1 \mathrm{~mL}$ of aqueous ferric chloride solution $(0.1 \%$, wt/vol) was added. After 10 min of standing at room temperature, the absorbance of resulting Prussian blue solution was measured using a Biochrom Libra S12 UV/Vis spectrophotometer (Biochrom Ltd.) at $700 \mathrm{~nm}$. The experimental steps were repeated with Milli-Q water as a blank. The reducing power of the sample was reported as absorbance at $700 \mathrm{~nm}$ after subtracting the absorbance value of the blank. A higher absorbance value indicated greater reducing power.

Assay of DPPH Radical Scavenging Activity. The radical scavenging activity (RSA) of WSPE was measured against DPPH radical as described by Siow and Gan (2013) with some modifications. Briefly, $20 \mu \mathrm{L}$ of aqueous WSPE (at $0.5 \mathrm{mg}$ of protein $/ \mathrm{mL}$ ) was mixed with $1.0 \mathrm{~mL}$ of DPPH reagent (50 $\mu M$ in ethanol). The mix was vortexed and left to stand for 30 min in dark. Then, the mix was clarified by centrifuging at $16,000 \times$ $g$ (5415C microcentrifuge, Eppendorf, Hamburg, Germany) for $5 \mathrm{~min}$ at room temperature and subjected for absorbance measurement at $517 \mathrm{~nm}$. For the blank, Milli-Q water was used instead of sample. Antioxidant activity of WSPE was calculated using equation [6]:

RSA, $\%=\frac{(\text { Absorbance of blank }- \text { Absorbance of sample })}{\text { Absorbance of blank }} \times 100$.

Assay of ABTS Radical Scavenging Activity. The ABTS $^{\bullet+}$ scavenging activity of WSPE was assayed according to the method described by Ozgen et al. (2006) with some modifications. The working solution of $\mathrm{ABTS}^{\bullet+}$ was prepared by mixing stock solutions of $7.4 \mathrm{~m} M$ ABTS (molecular $=548.68$ ) in sodium acetate buffer $(20 \mathrm{mM}, \mathrm{pH} 4.5)$ and $2.6 \mathrm{mM}$ potassium persulphate (molecular $=270.32$ ) aqueous solution in equal quantities and allowing them to react for 12 to $16 \mathrm{~h}$ at room temperature in the dark. One milliliter of $\mathrm{ABTS}^{\bullet+}$ solution was then diluted by mixing with 50 to $60 \mathrm{~mL}$ of sodium acetate buffer (20 mM, pH 4.5) to obtain an absorbance of $0.70 \pm 0.02$ at $734 \mathrm{~nm}$ after equilibration at $30^{\circ} \mathrm{C}$. The $\mathrm{ABTS}^{\bullet+}$ reagent was prepared daily.

Exactly $10 \mu \mathrm{L}$ of aqueous WSPE (at $0.5 \mathrm{mg}$ of protein $/ \mathrm{mL}$ ) was added to $1 \mathrm{~mL}$ of the $\mathrm{ABTS}^{\bullet+}$ reagent and incubated at $30^{\circ} \mathrm{C}$ for $6 \mathrm{~min}$ after vortexing. The absorbance of the mix was measured at $734 \mathrm{~nm}$. Similarly, $10 \mu \mathrm{L}$ of Milli-Q water was used instead of the sample for the blank. Radical scavenging activity was calculated using equation [6].

Assay of Hydroxyl Radical Scavenging Activity. The scavenging capacity of WSPE for hydroxyl radical was assayed according to the method described by Zheng et al. (2015) with some modifications. Briefly, $500 \mu \mathrm{L}$ of aqueous ferrous sulfate $(2 \mathrm{mM})$ and $100 \mu \mathrm{L}$ of aqueous hydrogen peroxide $(2 \mathrm{mM})$ were mixed to $20 \mu \mathrm{L}$ of sample $(0.1 \mathrm{mg}$ of protein $/ \mathrm{mL})$. The reaction mixture was left for $10 \mathrm{~min}$ and then $500 \mu \mathrm{L}$ of aqueous salicylic acid $(2.5 \mathrm{mM})$ was added. The mixture was incubated for $30 \mathrm{~min}$ at $37^{\circ} \mathrm{C}$ and subjected for absorbance measurement at $510 \mathrm{~nm}$. Milli-Q water was used for the blank (in place of salicylic acid) and the 
control (in place of sample) in the reaction. Hydroxyl radical scavenging activity (HRSA) of the WSPE was calculated using equation [7]

$$
\operatorname{HRSA}(\%)=\left[1-\frac{A_{\mathrm{s}}-A_{\mathrm{b}}}{A_{\mathrm{c}}}\right] \times 100,
$$

where $A_{\mathrm{s}}, A_{\mathrm{b}}$, and $A_{\mathrm{c}}$ were absorbance for sample, blank, and control, respectively.

\section{Statistical Analyses}

Experiments were conducted as a randomized splitplot blocked design in time with types of yogurt as the main plot, prebiotic addition and time as subplots. The design was replicated independently on 3 different occasions with subsequent subsampling giving at least 6 observations $(\mathrm{n} \geq 6)$. Results were analyzed using GLM procedure of the SAS System (SAS, 1996) to explore the effects of probiotic and potential prebiotic, PPP, and inulin addition on properties of different yogurt types over time at 3 levels (d 1, 14, and 28) of storage. Significance level was considered at $P<0.05$. Chemometric methods such as hierarchical cluster analysis (HCA) and principal component analysis (PCA) were employed to discriminate yogurts with different culture and prebiotic combinations (Matera et al., 2014). The HCA categorized different yogurts into clusters based on their similarities by applying the squared Euclidean distance and Ward linkage methods to the standardized data set (z-scores). The eigenvalues were extracted from the correlation matrix; varimax rotation was used in the PCA to produce orthogonal transformations to the reduced factors to identify the high and low correlations. Pearson correlation, HCA, and PCA were performed on d 1 results using SPSS 22.0 (SPSS Inc., Chicago, IL).

\section{RESULTS AND DISCUSSION}

\section{Viability of Starter and Probiotic Cultures in Yogurt During Refrigerated Storage}

Prebiotics are usually supplemented to fermented milk and milk products for stimulation of the growth of probiotic strains, which are a part of the human colonic microbiota. Because of widened attention on lactobacilli, the effect of addition of PPP as a potential prebiotic on the viable count of probiotic ( $L$. acidophilus, $L$. casei, and L. paracasei) and starter (S. thermophilus, $L$. bulgaricus) cultures in yogurt was investigated during $28 \mathrm{~d}$ of refrigerated storage and reported in Tables 1 and 2.

Supplementation of milk with selected probiotic organisms and PPP resulted in a substantially faster lowering of $\mathrm{pH}$ (data not shown), suggesting a higher rate of acid production compared with control yogurt. The viability of $S$. thermophilus and L. bulgaricus reduced significantly during the 28-d storage period by half of a log cycle in all types of yogurt (Table 1). Table 2 shows the viable count of probiotic organisms before fermentation and during refrigerated storage for yogurt containing PPP, yogurt with inulin, and control yogurt. Overall, the presence of PPP in yogurts effectively improved probiotic growth, comparable to that of inulin and one $\log$ cycle higher than the nonsupplemented control sample. Stability of the probiotic organisms in

Table 1. Viability of starter culture in yogurts supplemented with or without pineapple peel powder (PPP) or inulin during $28 \mathrm{~d}$ of storage at $4^{\circ} \mathrm{C} ; 0 \mathrm{~h}$ counts represent count of starter culture in yogurt mix taken immediately after culture addition ${ }^{1}$

\begin{tabular}{|c|c|c|c|c|c|c|c|c|c|}
\hline & & \multicolumn{8}{|c|}{ Viable count (log cfu/g) } \\
\hline SC & None & $7.41^{\mathrm{a}, \mathrm{D}}$ & $9.18^{\mathrm{c}, \mathrm{A}}$ & $8.98^{\mathrm{d}, \mathrm{B}}$ & $8.58^{\mathrm{d}, \mathrm{C}}$ & $7.33^{\mathrm{a}, \mathrm{D}}$ & $8.13^{\mathrm{c}, \mathrm{A}}$ & $8.04^{\mathrm{d}, \mathrm{B}}$ & $7.51^{\mathrm{f}, \mathrm{C}}$ \\
\hline $\mathrm{SC}$ & Inulin & $7.40^{\mathrm{a}, \mathrm{D}}$ & $9.23^{\mathrm{bc}, \mathrm{A}}$ & $9.03^{\mathrm{cd}, \mathrm{B}}$ & $8.62^{\mathrm{cd}, \mathrm{C}}$ & $7.31^{\mathrm{a}, \mathrm{D}}$ & $8.27^{\mathrm{a}, \mathrm{A}}$ & $8.20^{\mathrm{a}, \mathrm{B}}$ & $7.90^{\mathrm{a}, \mathrm{C}}$ \\
\hline $\mathrm{SC}$ & PPP & $7.41^{\mathrm{a}, \mathrm{D}}$ & $9.27^{\mathrm{ab}, \mathrm{A}}$ & $9.10^{\mathrm{ab}, \mathrm{B}}$ & $8.72^{\mathrm{b}, \mathrm{C}}$ & $7.33^{\mathrm{a}, \mathrm{D}}$ & $8.19^{\mathrm{b}, \mathrm{A}}$ & $8.13^{\mathrm{bc}, \mathrm{B}}$ & $7.70^{\mathrm{d}, \mathrm{C}}$ \\
\hline $\mathrm{SC}+\mathrm{PC}$ & PPP & \multirow{2}{*}{\multicolumn{4}{|c|}{$0.02^{9.15}$}} & \multirow{2}{*}{\multicolumn{4}{|c|}{$0.02^{8.11}$}} \\
\hline $\mathrm{SEM}^{3}$ & & & & & & & & & \\
\hline
\end{tabular}

\footnotetext{
${ }^{\mathrm{a}-\mathrm{f}}$ Different lowercase superscripts in the same column depict the significant difference between means for yogurt types $(P<0.05)$.

${ }^{\mathrm{A}-\mathrm{D}}$ Different uppercase superscripts in the same row depict the significant difference between means for yogurts with the same culture and prebiotic combination at $\mathrm{d} 1,14$, and 28 of refrigerated storage $(P<0.05)$.

${ }^{1}$ Results are expressed as mean of 3 trials.

${ }^{2} \mathrm{SC}=$ starter culture $(S$. thermophilus + L. bulgaricus $) ; \mathrm{PC}=$ probiotic culture (Lactobacillus acidophilus + Lactobacillus casei + Lactobacillus paracasei).

${ }^{3}$ Pooled standard error of the mean for predetermined $P<0.05$.
} 
Table 2. Viability of probiotic cultures in yogurts supplemented with or without pineapple peel powder (PPP) or inulin during $28 \mathrm{~d}$ of storage at $4^{\circ} \mathrm{C} ; 0 \mathrm{~h}$ counts represent probiotic count in yogurt mix taken immediately after culture addition ${ }^{1}$

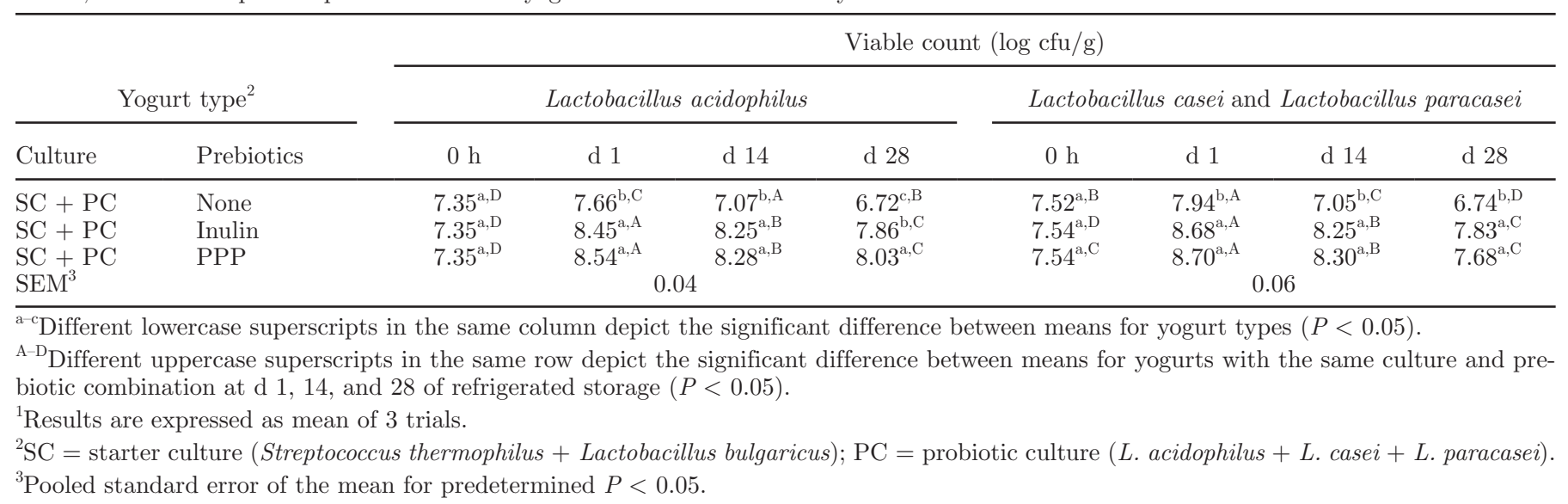

PPP enriched medium might be due to buffering capacity of the prebiotics, which would aid in maintaining the viability of live bacterial cells (Kailasapathy et al., 2008). It has been reported that PPP may serve as a source of growth factors for improved growth of probiotic bacteria in yogurt (Diaz-Vela et al., 2013). Iyer and Kailasapathy (2005) also reported enhanced survival of probiotic organisms under in vitro acidic and bile salt conditions when the organisms were coencapsulated with prebiotics such as Hi-maize (Starch Australasia Ltd., Lane Cove, Australia). Thus, addition of PPP resulted in improved survival and metabolic activity during storage at $4^{\circ} \mathrm{C}$. Conversely, factors such as postfermentation acidification and dissolved oxygen may adversely influence the viability of probiotic strains in fermented milk (Vasiljevic and Shah, 2008). The reported loss of probiotic viability in yogurts during storage is likely due to acid injury, as titratable acidity increases significantly during storage (Table 3; Donkor et al., 2006). Nonetheless, counts of the probiotic organisms during $28 \mathrm{~d}$ of cold storage were sufficient to exhibit probiotic effect on the consumer as the reported minimum therapeutic count of $10^{6} \mathrm{cfu} / \mathrm{g}$ (Lourens-Hattingh and Viljoen, 2001) is below that obtained in the current study. These observations point out an in vitro symbiotic effect of PPP on selected probiotic organisms similar to previous reports (Sendra et al., 2008; do Espírito Santo et al., 2012), where fibers from various fruit processing by-products stimulated the growth of probiotic strains.

\section{Titratable Acidity of Yogurt During Refrigerated Storage}

In all yogurt samples, the titratable acidity increased significantly $(P<0.05)$ during $28 \mathrm{~d}$ of storage (Table
3), suggesting continued production of organic acids during storage. Supplementation with PPP or inulin increased the acidifying ability of starter and probiotic cultures during refrigerated storage. Similar acidification in yogurt-type products was observed during refrigerated storage in various studies (Gilliland et al., 2002; Donkor et al., 2006).

\section{Degree of Proteolysis in Yogurt During Refrigerated Storage}

Lactic acid bacteria produce proteolytic enzymes during yogurt manufacturing which cleave peptide bonds of milk proteins leading to generation of peptides and free AA (Donkor et al., 2007c). The extent of protein hydrolysis in yogurt samples during storage was estimated by determining free amino groups and results reported as degree of hydrolysis in Table 3. In all samples, the degree of proteolysis increased significantly $(P<0.05)$ over a storage period of $28 \mathrm{~d}$, suggesting continuation of proteolytic activities during storage. Additionally, a significant $(P<0.05)$ increase in proteolytic activity was observed in probiotic yogurt compared with plain yogurt. Furthermore, proteolytic activities increased significantly $(P<0.05)$ in PPP- or inulin-supplemented yogurt compared with the nonsupplemented control yogurt. Interactions among yogurt types, prebiotic (inulin or PPP) additions, and storage time (Table 4) indicated that the prebiotics increased the generation of new peptides in probiotic yogurts compared with plain yogurts during storage. Pineapple powders contain dietary fibers, proteins, and minerals, including divalent cations, and serve as growth factors or growth promoters for probiotics in the yogurts (Diaz-Vela et al., 2013). For better growth, bacterial cells require free AA for protein synthesis; therefore, bacterial extracellular 
Table 3. Titratable acidity, degree of protein hydrolysis, and antimutagenic activity of plain and probiotic yogurts supplemented with or without pineapple peel powder (PPP) or inulin during $28 \mathrm{~d}$ of storage at $4^{\circ} \mathrm{C}^{1}$

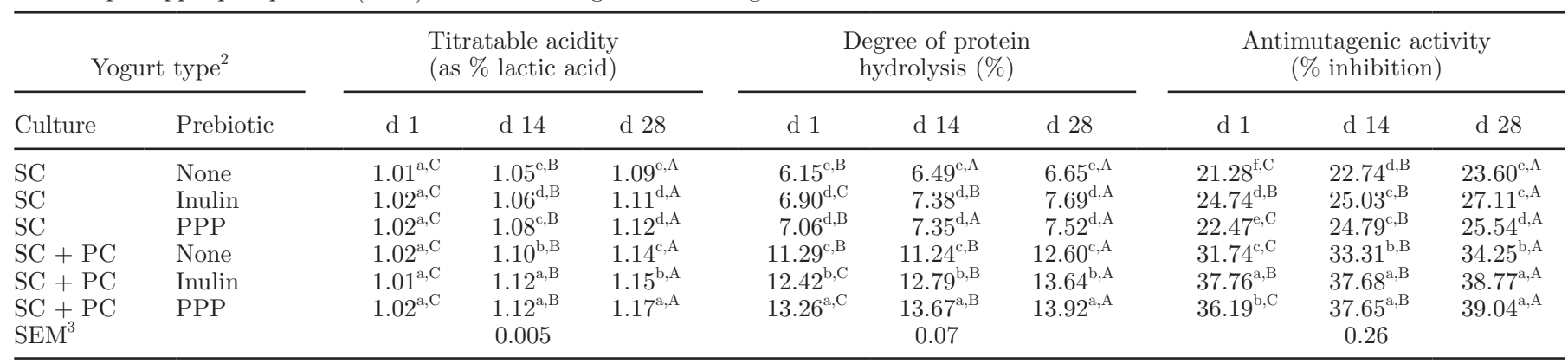

${ }^{\mathrm{a}-\mathrm{e}}$ Different lowercase superscripts in the same column depict the significant difference between means for yogurt types $(P<0.05)$.

${ }^{\mathrm{A}-\mathrm{C}}$ Different uppercase superscripts in the same row depict the significant difference between means for yogurts with the same culture and prebiotic combination at $\mathrm{d} 1,14$, and 28 of refrigerated storage $(P<0.05)$.

${ }^{1}$ Results are expressed as mean of 3 trials.

${ }^{2} \mathrm{SC}=$ starter culture (Streptococcus thermophilus + Lactobacillus bulgaricus) $; \mathrm{PC}=$ probiotic culture (Lactobacillus acidophilus + Lactobacillus casei + Lactobacillus paracasei)

${ }^{3}$ Pooled standard error of the mean for predetermined $P<0.05$.

proteinases hydrolyze milk proteins into oligopeptides and further hydrolysis by intracellular peptidases of peptides into AA (Donkor et al., 2007c). The mineralrich PPP likely stimulated bacterial enzymes, resulting in higher proteolytic activities.

The generation of peptides from milk proteins during yogurt manufacturing was confirmed by profiling WSPE from yogurts using a reversed-phase HPLC, as presented in Figure 1. Probiotic yogurts supplemented with inulin or PPP (yogurts 5 and 6) exhibited more peaks (peptides) compared with nonsupplemented plain yogurt (yogurt 1) and reconstituted skim milk. The peptide profiles obtained are in line with previous study (Miclo et al., 2012), who reported casein break down by cell envelope proteinases of $S$. thermophilus. Several peptides may be generated during storage and may display different biological activities. A study by van Boekel et al. (1993), found that the generated peptides from pepsin hydrolysis of casein were more potent in antimutagenic activity than intact casein.

\section{Antimutagenic Activity of Yogurt During Refrigerated Storage}

Mutagen inhibitory activity of WSPE was evaluated using Ames test by assessing inhibitory activity of peptides against sodium azide on S. typhimurium and presented in Table 3 . In all yogurt samples, the antimutagenic activities of the WSPE at the end of storage increased significantly $(P<0.05)$ compared with the first day of storage, indicating increased generation of these peptides during storage. In addition, enhanced antimutagenic activity was also observed in the probiotic yogurts compared with control. The an-

Table 4. Analysis of variance depicting the significance $(P<0.05)$ of types of yogurt (plain and probiotic yogurts), prebiotics (inulin and pineapple peel powder), storage time at 3 levels $(\mathrm{d} 1,14$, and 28$)$ and their effects on degree of protein hydrolysis, antimutagenic and antioxidant activities

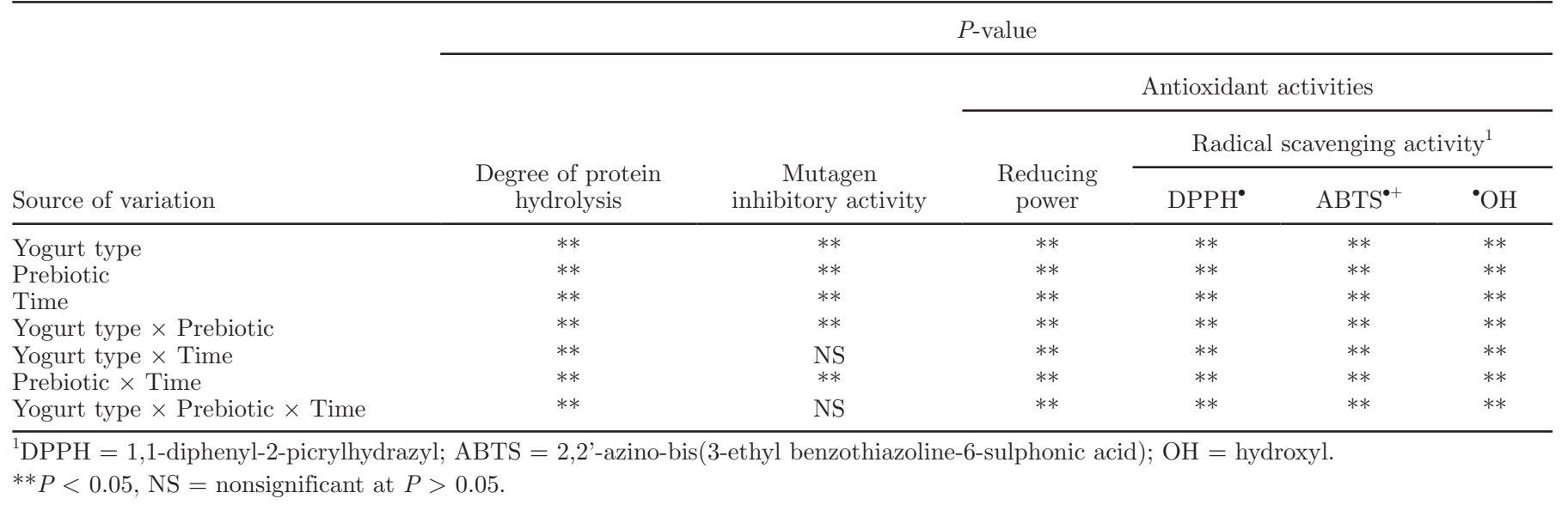



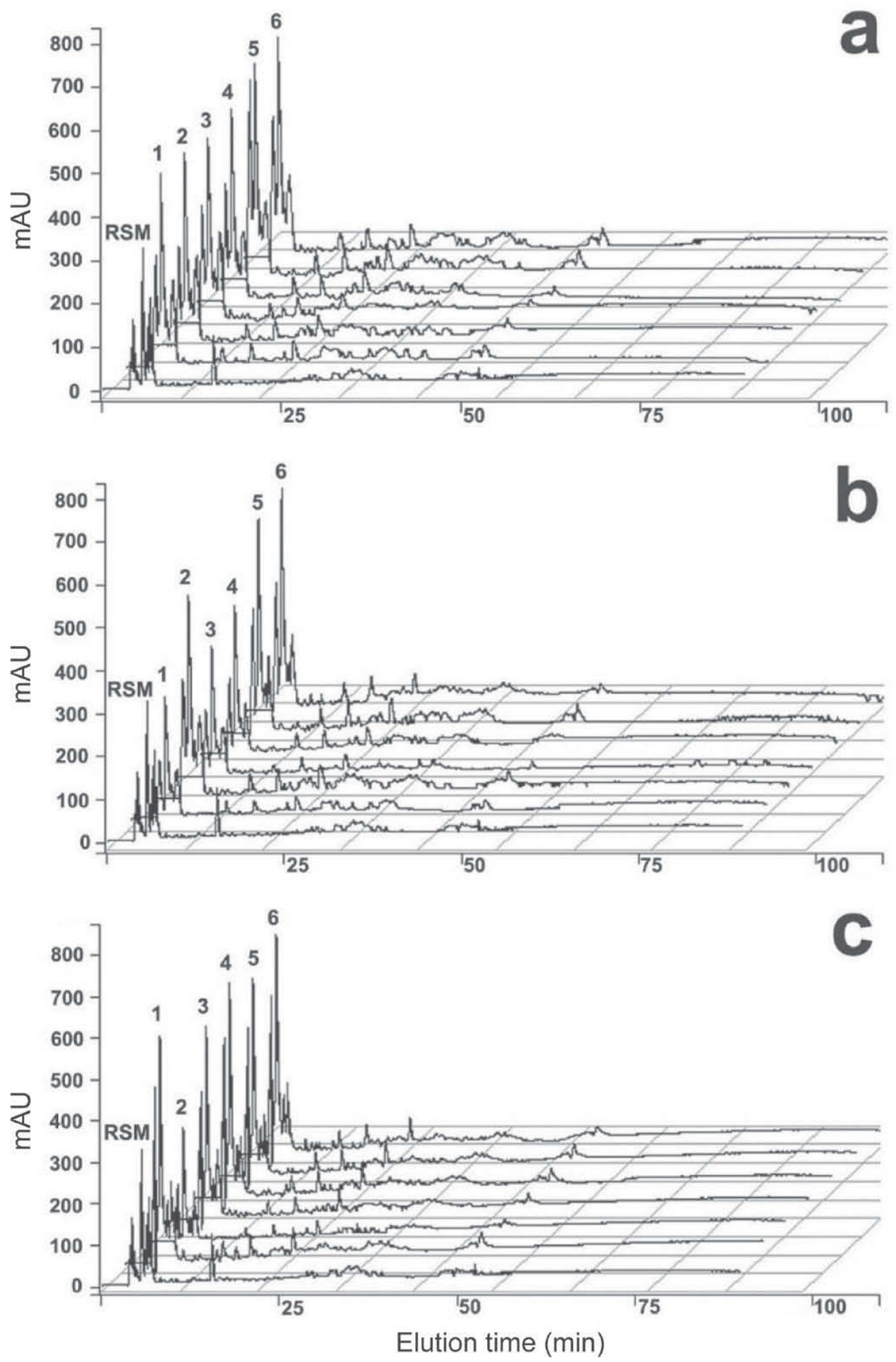

Figure 1. Reversed-phase HPLC profile of crude water-soluble peptide extract of yogurt types 1, 2, 3, 4, 5 , and 6 during $28 \mathrm{~d}$ of refrigerated storage at (a) d 1, (b) 14, and (c) 28 compared with reconstituted skim milk (RSM). Yogurts denoted 1, 2, and 3 were plain yogurts with or without prebiotic supplementation; yogurt 1 was without supplementation, whereas yogurts 2 and 3 were supplemented with inulin and pineapple peel powder (PPP), respectively. Yogurts denoted 4, 5, and 6 were probiotic yogurts without prebiotic, with inulin, and PPP supplementation, respectively. The peptides were eluted using a linear gradient from 100 to $0 \%$ solvent A (0.1\% trifluoroacetic acid in Milli-Q water from a Millipore water-purification system; Millipore, North Ryde, Australia) in solvent B ( $0.1 \%$ trifluoroacetic acid in acetonitrile) over 90 min at a flow rate of $0.75 \mathrm{~mL} / \mathrm{min}$ and detected by UV absorption at $215 \mathrm{~nm}$. 
timutagenic activity in yogurt supplemented with PPP was similar to that of inulin-supplemented yogurts and both showed significantly higher activity compared with nonsupplemented control yogurts. The insignificant interactions among yogurt types, prebiotic (inulin or PPP) addition, and storage time (Table 4) indicated that increment pattern of antimutagenic activities for both plain and probiotic yogurts during storage was similar because of prebiotic supplementation. Pearson correlation suggested a direct relationship between degree of proteolysis and antimutagenic activity $(P<$ 0.01, $\mathrm{r}=0.96)$; Bakalinsky et al. (1996) also reported of similar results.

\section{In Vitro Antioxidant Activity of Yogurt During Refrigerated Storage}

An antioxidant compound can protect the human body by scavenging free radicals, such as reactive oxygen species, and increase shelf life of foodstuffs by retarding the process of lipid peroxidation through hydrogen atom or electron transfer. For instance, donation of hydrogen ions involves interrupting free radical chain reactions, which is a basis for the assessment of reducing power. Additionally, the reaction mechanisms involving mainly a hydrogen atom transfer is basis for DPPH-based methods and both hydrogen atom transfer and single electron transfer for ABTS-based methods (Gülçin, 2012). Due to the involvement of a cascade of reaction steps in an oxidation process, protein hydrolyzates can exhibit antioxidant activities through multiple reaction mechanisms (Chen et al., 2003). Thus, several different assays must be performed to provide a comprehensive information about total antioxidant capacity of the compound tested. This justifies the current study of evaluation for the antioxidant potential of WSPE by conducting 4 different assays. Reducing power and scavenging capacities for DPPH, ABTS, and hydroxyl radicals of WSPE were measured during 28 $\mathrm{d}$ of refrigerated storage and presented in Table 5. All yogurt samples exhibited varying degrees of reducing power, scavenging capacities for DPPH, ABTS, and hydroxyl radicals, indicating differences in generated WSPE of the yogurts. The activities increased significantly $(P<0.05)$ during storage compared with the first day. Furthermore, these activities were stronger in PPP- or inulin-supplemented yogurt compared with the nonsupplemented control yogurt. This implied that that the generated peptides in WSPE acted as potent antioxidant compounds. The interactions among yogurt types, prebiotic (inulin or PPP) additions, and storage time (Table 4) showed that prebiotics influenced differently the antioxidant capacities of WSPE in plain and probiotic yogurts during storage.
A positive correlation between degree of proteolysis with reducing power $(P<0.01, \mathrm{r}=0.91)$, scavenging capacities of DPPH $(P<0.01, \mathrm{r}=0.76)$, ABTS $(P<$ $0.01, \mathrm{r}=0.89)$, and hydroxyl $(P<0.01, \mathrm{r}=0.98)$ radicals were observed. Several potent antioxidant peptides liberated from milk proteins have been reported, such as Tyr-Val-Pro-Glu-Pro-Phe, Phe-Pro-Tyr-Cys-Ala-Pro, Phe-Gly-Gly-Met-Ala-His, Val-Tyr-Pro-Phe, and TyrPro-Pro-Tyr-Glu-Thr-Tyr from casein hydrolyzates of goat milk using a combination of alkaline and neutral proteases (Li et al., 2013); Trp-Tyr-Ser-Leu-Ala-MetAla-Ala-Ser-Asp-Ile from $\beta$-lactoglobulin hydrolyzates using corolase PPP (Hernández-Ledesma et al., 2005); and Ala-Arg-His-Pro-His-Pro-His-Leu-Ser-Phe-Met from fermented milk by using Lactobacillus delbrueckii ssp. bulgaricus (Kudoh et al., 2001). Furthermore, lowmolecular weight casein hydrolyzates displayed strong radical scavenging activities (Kim et al., 2007). The antioxidative capacity of a peptide depends on various attributes including sequence, composition of AA, configuration, and concentration of the peptide (Phanturat et al., 2010). Again, the type of enzymes involved in the hydrolysis of protein is also a determining factor (Foh et al., 2010). In addition, Rajapakse et al. (2005) reported that hydrolyzates containing Pro, His, Met, Tyr, Val, Lys, Cys, and Gln displayed strong radical scavenging capacity.

\section{Effect of PPP and Probiotic Addition on Overall Characteristics of Yogurts}

Cluster analysis was performed using hierarchical clustering method with Ward's linkage and revealed 2 clusters based on similarities in titratable acidity, degree of protein hydrolysis, and antimutagenic and antioxidant activities (evaluated measuring reducing power and scavenging capacity for $\mathrm{DPPH}^{\bullet}, \mathrm{ABTS}^{\bullet+}$, and ${ }^{\circ} \mathrm{OH}$ radicals) during the first day of storage at $4^{\circ} \mathrm{C}$ (Figure 2A). Plain and probiotic yogurts were arranged in 2 separate clusters. Inclusion of probiotic cultures resulted in pronounced effects on the measured variables compared with the supplementation of inulin or PPP.

Principal component analysis was also conducted and 2 components were identified based on Kaiser's criterion of eigenvalues greater than 1.0 (Figure 2B). The first component explains higher variance $(76.95 \%)$ than the second component (17.60\%). Samples are distributed in all 4 quadrants of the score plot. Yogurts prepared with starter culture only are at the left quadrants, whereas yogurts prepared with both starter and probiotic cultures are at the right quadrants. Yogurt 6 , designated in a separate quadrant, shows higher antioxidant and antimutagenic activities, indicating differences in properties compared with the other studied yogurts. 

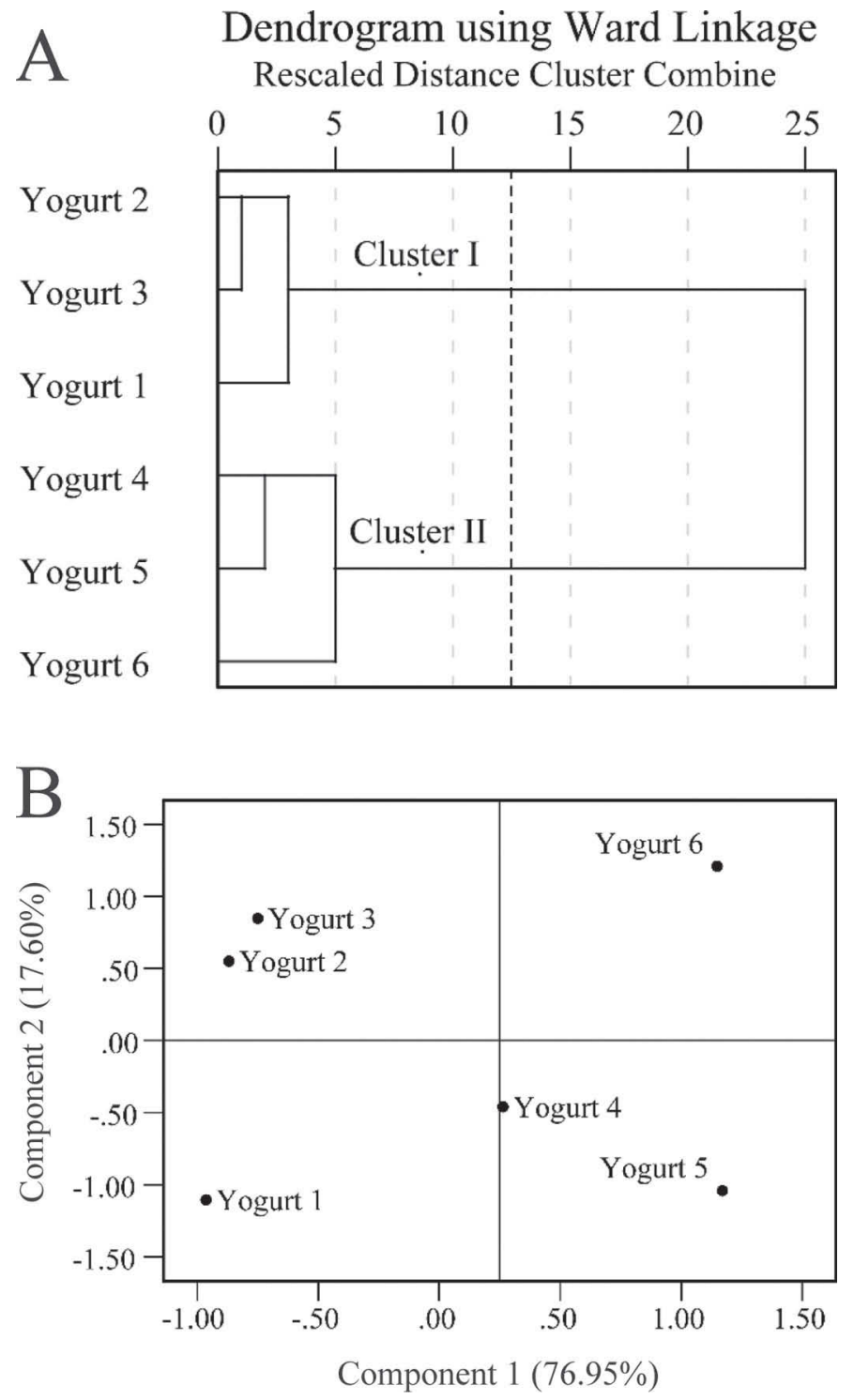

Figure 2. Dendrogram (A) exhibits the clustering of yogurts according to similarities among measured variables. Score plot (B) is of principal components of measured variables in yogurts stored at $4^{\circ} \mathrm{C}$ in d 1 . The measured variables were titratable acidity, degree of protein hydrolysis, antimutagenic and antioxidant activities. Yogurts denoted 1,2 , and 3 were fermented using starter culture only, whereas yogurts denoted 4,5 , and 6 were fermented using both starter and probiotic cultures. Yogurts 2 and 5 were supplemented with inulin, yogurts 3 and 6 were supplemented with pineapple peel powder, and yogurts 1 and 4 were nonsupplemented control yogurts.

\section{CONCLUSIONS}

Improved growth and retention of viability of $L$. acidophilus (ATCC 4356), L. casei (ATCC 393), and L. paracasei spp. paracasei (ATCC BAA52) was observed during refrigerated storage at $4^{\circ} \mathrm{C}$ for $28 \mathrm{~d}$ in synbiotic yogurt formulations with added PPP. The proteolytic activities of cultures were enhanced substantially in

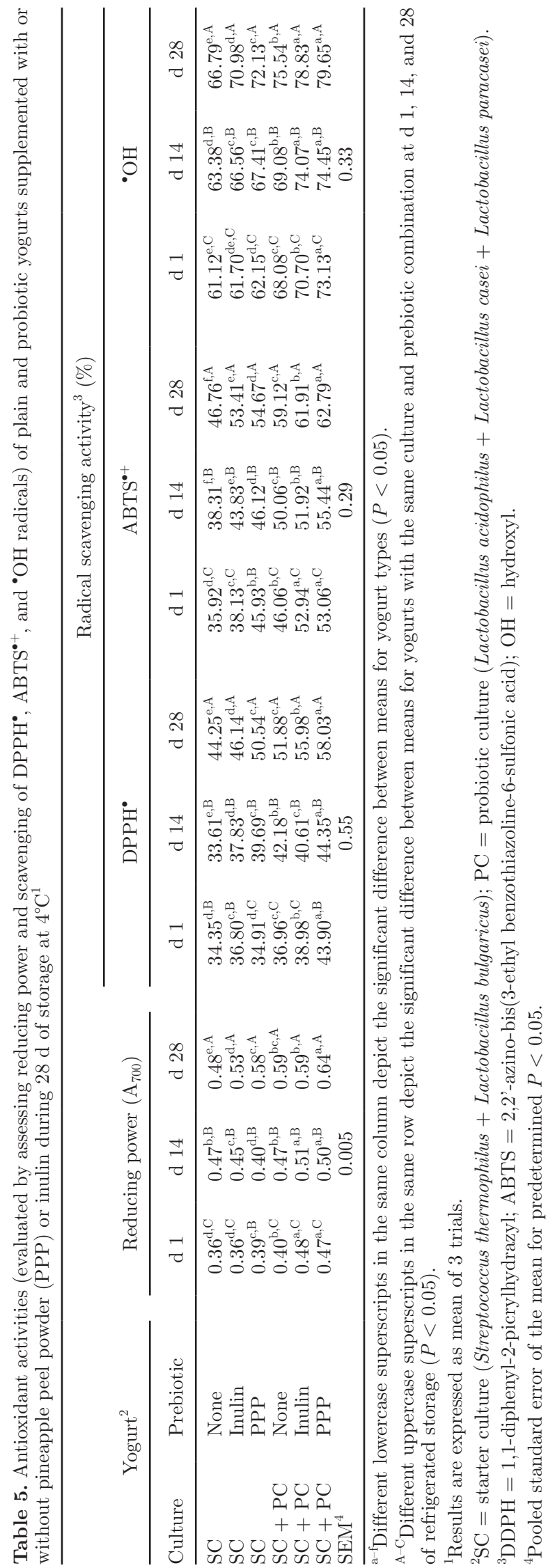


the presence of prebiotic during storage. All WSPE prepared from yogurt samples possessed antimutagenic activity, which increased during storage. In addition, the WSPE exhibited excellent antioxidant properties measured through in vitro assays employing $\mathrm{DPPH}^{\bullet}$, $\mathrm{ABTS}^{\bullet+}$, and ${ }^{\bullet} \mathrm{OH}$ free radicals. Interestingly, WSPE of the probiotic yogurt with PPP exhibited the most potent antimutagenic and antioxidant activities. In addition, incorporation of PPP and probiotics in food products would provide new opportunities in the design and preparation of novel functional foods. Establishing the stability of bioactive peptides during refrigerated storage would add in expanding the functional food market as well. However, these findings demand further investigations to identify and purify these bioactive peptides from WSPE and to understand the possible health benefits, as well as their effect on sensory attributes of food products enriched with protein hydrolyzates.

\section{ACKNOWLEDGMENTS}

The authors are grateful to the Australian government for offering an Australia Awards Scholarships and Australia Awards Leadership Program place to B. N. P. Sah.

\section{REFERENCES}

Al-Sheraji, S. H., A. Ismail, M. Y. Manap, S. Mustafa, and R. M. Yusof. 2012. Viability and activity of bifidobacteria during refrigerated storage of yoghurt containing Mangifera pajang fibrous polysaccharides. J. Food Sci. 77:M624-M630. http://dx.doi. org/10.1111/j.1750-3841.2012.02955.x.

Al-Sheraji, S. H., A. Ismail, M. Y. Manap, S. Mustafa, R. M. Yusof, and F. A. Hassan. 2013. Prebiotics as functional foods: A review. J. Funct. Foods 5:1542-1553. http://dx.doi.org/10.1016/j. jff.2013.08.009.

Bakalinsky, A. T., S. R. Nadathur, J. R. Carney, and S. J. Gould. 1996. Antimutagenicity of yogurt. Mutat. Res. 350:199-200. http://dx.doi.org/10.1016/0027-5107(95)00113-1.

Bhat, Z. F., and H. Bhat. 2011. Milk and dairy products as functional foods: A review. Int. J. Dairy Sci. 6:1-12. http://dx.doi. org/10.3923/ijds.2011.1.12.

Bradford, M. M. 1976. A rapid and sensitive method for the quantitation of microgram quantities of protein utilizing the principle of protein dye binding. Anal. Biochem. 72:248-254.

Chen, J., H. Lindmark-Månsson, L. Gorton, and B. Åkesson. 2003. Antioxidant capacity of bovine milk as assayed by spectrophotometric and amperometric methods. Int. Dairy J. 13:927-935. http://dx.doi.org/10.1016/S0958-6946(03)00139-0.

Choi, J., L. Sabikhi, A. Hassan, and S. Anand. 2012. Bioactive peptides in dairy products. Int. J. Dairy Technol. 65:1-12. http:// dx.doi.org/10.1111/j.1471-0307.2011.00725.x.

Coman, M. M., M. C. Verdenelli, C. Cecchini, S. Silvi, A. Vasile, G. E. Bahrim, C. Orpianesi, and A. Cresci. 2013. Effect of buckwheat flour and oat bran on growth and cell viability of the probiotic strains Lactobacillus rhamnosus IMC 501 ${ }^{\circledR}$, Lactobacillus paracasei IMC $502{ }^{\circledR}$ and their combination $\mathrm{SYNBIO}{ }^{\circledR}$, in synbiotic fermented milk. Int. J. Food Microbiol. 167:261-268. http://dx.doi. org/10.1016/j.ijfoodmicro.2013.09.015.
Corona-Hernandez, R. I., E. Álvarez-Parrilla, J. Lizardi-Mendoza, A. R. Islas-Rubio, L. A. de la Rosa, and A. Wall-Medrano. 2013. Structural stability and viability of microencapsulated probiotic bacteria: A review. Compr. Rev. Food Sci. Food Saf. 12:614-628. http://dx.doi.org/10.1111/1541-4337.12030.

Cruz, A. G., W. F. Castro, J. A. F. Faria, H. M. A. Bolini, R. M. S. Celeghini, R. S. L. Raices, C. A. F. Oliveira, M. Q. Freitas, C. A. Conte Júnior, and E. T. Mársico. 2013. Stability of probiotic yogurt added with glucose oxidase in plastic materials with different permeability oxygen rates during the refrigerated storage. Food Res. Int. 51:723-728. http://dx.doi.org/10.1016/j. foodres.2013.01.028.

Day, L., R. B. Seymour, K. F. Pitts, I. Konczak, and L. Lundin. 2009. Incorporation of functional ingredients into foods. Trends Food Sci. Technol. 20:388-395. http://dx.doi.org/10.1016/j. tifs.2008.05.002.

Diaz-Vela, J., A. Totosaus, A. E. Cruz-Guerrero, and M. De Lourdes Pérez-Chabela. 2013. In vitro evaluation of the fermentation of added-value agroindustrial by-products: Cactus pear (Opuntia ficus-indica L.) peel and pineapple (Ananas comosus) peel as functional ingredients. Int. J. Food Sci. Technol. 48:1460-1467. http://dx.doi.org/10.1111/ijfs.12113.

do Espírito Santo, A. P., N. S. Cartolano, T. F. Silva, F. A. S. M. Soares, L. A. Gioielli, P. Perego, A. Converti, and M. N. Oliveira. 2012. Fibers from fruit by-products enhance probiotic viability and fatty acid profile and increase CLA content in yoghurts. Int. J. Food Microbiol. 154:135-144. http://dx.doi.org/10.1016/j. ijfoodmicro.2011.12.025.

Donkor, O. N., A. Henriksson, T. K. Singh, T. Vasiljevic, and N. P. Shah. 2007b. ACE-inhibitory activity of probiotic yoghurt. Int. Dairy J. 17:1321-1331. http://dx.doi.org/10.1016/j. idairyj.2007.02.009.

Donkor, O. N., A. Henriksson, T. Vasiljevic, and N. P. Shah. 2006. Effect of acidification on the activity of probiotics in yoghurt during cold storage. Int. Dairy J. 16:1181-1189. http://dx.doi. org/10.1016/j.idairyj.2005.10.008.

Donkor, O. N., A. Henriksson, T. Vasiljevic, and N. P. Shah. 2007c. Proteolytic activity of dairy lactic acid bacteria and probiotics as determinant of growth and in vitro angiotensin-converting enzyme inhibitory activity in fermented milk. Lait 87:21-38. http:// dx.doi.org/10.1051/lait:2006023.

Donkor, O. N., S. L. I. Nilmini, P. Stolic, T. Vasiljevic, and N. P. Shah. 2007a. Survival and activity of selected probiotic organisms in set-type yoghurt during cold storage. Int. Dairy J. 17:657-665. http://dx.doi.org/10.1016/j.idairyj.2006.08.006.

Foh, M. B. K., I. Amadou, B. M. Foh, M. T. Kamara, and W. Xia. 2010. Functionality and antioxidant properties of tilapia (Oreochromis niloticus) as influenced by the degree of hydrolysis. Int. J. Mol. Sci. 11:1851-1869. http://dx.doi.org/10.3390/ijms11041851.

Gibson, G. R., H. M. Probert, J. Van Loo, R. A. Rastall, and M. B. Roberfroid. 2004. Dietary modulation of the human colonic microbiota: Updating the concept of prebiotics. Nutr. Res. Rev. 17:259-275. http://dx.doi.org/10.1079/NRR200479.

Gilliland, S. E., S. S. Reilly, G. B. Kim, and H. S. Kim. 2002. Viability during storage of selected probiotic lactobacilli and bifidobacteria in a yogurt-like product. J. Food Sci. 67:3091-3095. http:// dx.doi.org/10.1111/j.1365-2621.2002.tb08864.x.

Gülçin, I. 2012. Antioxidant activity of food constituents: An overview. Arch. Toxicol. 86:345-391. http://dx.doi.org/10.1007/s00204-011$0774-2$.

Hernández-Ledesma, B., A. Dávalos, B. Bartolomé, and L. Amigo. 2005. Preparation of antioxidant enzymatic hydrolysates from $\alpha$-lactalbumin and $\beta$-lactoglobulln. Identification of active peptides by HPLC-MS/MS. J. Agric. Food Chem. 53:588-593. http://dx.doi.org/10.1021/jf048626m.

Horwitz, W., and G. W. Latimer Jr. 2006. Official Methods of Analysis of AOAC International. 18th ed. AOAC International, Gaithersburg, Md.

Iyer, C., and K. Kailasapathy. 2005. Effect of co-encapsulation of probiotics with prebiotics on increasing the viability of encapsulated bacteria under in vitro acidic and bile salt condi- 
tions and in yogurt. J. Food Sci. 70:M18-M23. http://dx.doi. org/10.1111/j.1365-2621.2005.tb09041.x.

Jiang, H., T. Tong, J. Sun, Y. Xu, Z. Zhao, and D. Liao. 2014. Purification and characterization of antioxidative peptides from round scad (Decapterus maruadsi) muscle protein hydrolysate. Food Chem. 154:158-163. http://dx.doi.org/10.1016/j.foodchem.2013.12.074.

Jutamongkon, R., and S. Charoenrein. 2010. Effect of temperature on the stability of fruit bromelain from smooth cayenne pineapple. Kasetsart J. (Nat. Sci.) 44:943-948.

Kailasapathy, K., I. Harmstorf, and M. Phillips. 2008. Survival of Lactobacillus acidophilus and Bifidobacterium animalis ssp. lactis in stirred fruit yogurts. LWT Food Sci. Technol. (Campinas.) 41:1317-1322. http://dx.doi.org/10.1016/j.lwt.2007.08.009.

Kim, G. N., H. D. Jang, and C. I. Kim. 2007. Antioxidant capacity of caseinophosphopeptides prepared from sodium caseinate using $\mathrm{Al}-$ calase. Food Chem. 104:1359-1365. http://dx.doi.org/10.1016/j. foodchem.2007.01.065.

Kudoh, Y., S. Matsuda, K. Igoshi, and T. Oki. 2001. Antioxidative Peptide from Milk Fermented with Lactobacillus delbrueckii ssp. bulgaricus IFO13953. J. Jpn. Soc. Food Sci. 48:44-50.

Li, Z., A. Jiang, T. Yue, J. Wang, Y. Wang, and J. Su. 2013. Purification and identification of five novel antioxidant peptides from goat milk casein hydrolysates. J. Dairy Sci. 96:4242-4251. http:// dx.doi.org/10.3168/jds.2012-6511.

Lourens-Hattingh, A., and B. C. Viljoen. 2001. Yogurt as probiotic carrier food. Int. Dairy J. 11:1-17. http://dx.doi.org/10.1016/ S0958-6946(01)00036-X.

Mani-López, E., E. Palou, and A. López-Malo. 2014. Probiotic viability and storage stability of yogurts and fermented milks prepared with several mixtures of lactic acid bacteria. J. Dairy Sci. 97:2578-2590. http://dx.doi.org/10.3168/jds.2013-7551.

Matera, J. A., A. G. Cruz, R. S. L. Raices, M. C. Silva, L. C. Nogueira, S. L. Quitério, R. N. Cavalcanti, M. Q. Freiras, and C. A. Conte Júnior. 2014. Discrimination of Brazilian artisanal and inspected pork sausages: Application of unsupervised, linear and non-linear supervised chemometric methods. Food Res. Int. 64:380-386. http://dx.doi.org/10.1016/j.foodres.2014.07.003.

Miclo, L., E. Roux, M. Genay, E. Brusseaux, C. Poirson, N. Jameh, C. Perrin, and A. Dary. 2012. Variability of hydrolysis of $\beta-, \alpha_{\mathrm{s} 1^{-}}$, and $\alpha_{\mathrm{s} 2}$-caseins by 10 strains of Streptococcus thermophilus and resulting bioactive peptides. J. Agric. Food Chem. 60:554-565. http:// dx.doi.org/10.1021/jf202176d.

Ozgen, M., R. N. Reese, A. Z. Tulio Jr., J. C. Scheerens, and A R. Miller. 2006. Modified 2,2-azino-bis-3-ethylbenzothiazoline6-sulfonic acid (ABTS) method to measure antioxidant capacity of selected small fruits and comparison to ferric reducing antioxidant power (FRAP) and 2,2'-diphenyl-1-picrylhydrazyl (DPPH) methods. J. Agric. Food Chem. 54:1151-1157. http://dx.doi. org/10.1021/jf051960d.
Phanturat, P., S. Benjakul, W. Visessanguan, and S. Roytrakul. 2010. Use of pyloric caeca extract from bigeye snapper (Priacanthus macracanthus) for the production of gelatin hydrolysate with antioxidative activity. LWT - . Food Sci. Technol. (Campinas.) 43:8697. http://dx.doi.org/10.1016/j.lwt.2009.06.010.

Rajapakse, N., E. Mendis, W. K. Jung, J. Y. Je, and S. K. Kim. 2005. Purification of a radical scavenging peptide from fermented mussel sauce and its antioxidant properties. Food Res. Int. 38:175-182 http://dx.doi.org/10.1016/j.foodres.2004.10.002.

Roberfroid, M. 2007. Prebiotics: The concept revisited. J. Nutr. 137(Suppl 2):830S-837S

Sah, B. N. P., T. Vasiljevic, S. McKechnie, and O. N. Donkor. 2014. Effect of probiotics on antioxidant and antimutagenic activities of crude peptide extract from yogurt. Food Chem. 156:264-270. http://dx.doi.org/10.1016/j.foodchem.2014.01.105.

Sah, B. N. P., T. Vasiljevic, S. McKechnie, and O. N. Donkor. 2015 Identification of anticancer peptides from bovine milk proteins and their potential roles in management of cancer: A critical review. Compr. Rev. Food Sci. Food Saf. 14:123-138. http://dx.doi. org/10.1111/1541-4337.12126.

SAS. 1996. SAS/STAT Softwares: Changes and Enhancements Through Release 6.11. SAS Institute Inc., Cary, NC.

Sendra, E., P. Fayos, Y. Lario, J. Fernández-López, E. Sayas-Barberá, and J. Pérez-Alvarez. 2008. Incorporation of citrus fibers in fermented milk containing probiotic bacteria. Food Microbiol. 25:13-21. http://dx.doi.org/10.1016/j.fm.2007.09.003.

Shiby, V. K., and H. N. Mishra. 2013. Fermented Milks and milk products as functional foods - A review. Crit. Rev. Food Sci. Nutr. 53:482-496. http://dx.doi.org/10.1080/10408398.2010.547398.

Siow, H. L., and C. Y. Gan. 2013. Extraction of antioxidative and antihypertensive bioactive peptides from Parkia speciosa seeds. Food Chem. 141:3435-3442. http://dx.doi.org/10.1016/j foodchem.2013.06.030.

Thammarutwasik, P., T. Hongpattarakere, S. Chantachum, K. Kijroongrojana, A. Itharat, W. Reanmongkol, S. Tewtrakul, and B. Ooraikul. 2009. Prebiotics-A review. Songklanakarin J. Sci. Technol. 31:401-408.

van Boekel, M. A. J. S., C. N. J. M. Weerens, A. Holstra, C. E. Scheidtweiler, and G. M. Alink. 1993. Antimutagenic effects of casein and its digestion products. Food Chem. Toxicol. 31:731-737. http://dx.doi.org/10.1016/0278-6915(93)90144-N.

Vasiljevic, T., and N. P. Shah. 2008. Probiotics-From Metchnikoff to bioactives. Int. Dairy J. 18:714-728. http://dx.doi.org/10.1016/j. idairyj.2008.03.004.

Zheng, X. Q., J. T. Wang, X. L. Liu, Y. Sun, Y. J. Zheng, X. J. Wang, and Y. Liu. 2015. Effect of hydrolysis time on the physicochemical and functional properties of corn glutelin by Protamex hydrolysis. Food Chem. 172:407-415. http://dx.doi.org/10.1016/j foodchem.2014.09.080 